\title{
高強度鋼における内部き裂発生寿命と疲労限度の実験的推定*
}

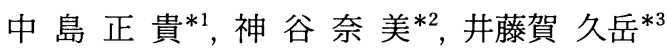 \\ 戸 梶 惠 郎*4, 高 行 男*3
}

\section{Experimental Estimation of Subsurface Crack Initiation Lives and Intrinsic Fatigue Limit in a High Strength Steel}

Masaki NAKAJIMA*5, Nami KAMIYA, Hisatake ITOGA, Keiro TOKAJI and Haeng-Nam KO

${ }^{* 5}$ Department of Mechanical Engineering, Toyota College of Technology, 2-1 Eisei-cho, Toyota-shi, Aichi, 471-8525 Japan

\begin{abstract}
Fatigue tests under two-step variable amplitude loading were conducted on a high carbon chromium steel, JIS SUJ 2, in order to clarify the crack initiation lives and the intrinsic fatigue limit in subsurface fracture. Particular attention was paid to the granular area around the non-metallic inclusion in fish-eye. The granular area does not appear in short life region at high stress levels, but appears in long life region at low stress levels. Using this property, low-high sequences with a different cycle ratio at low stress level were applied to shot-peened specimens. If the granular area is observed after testing, then it is assumed that the granular area is generated in the cycle ratio examined. It was found that subsurface crack nucleation took place at the early stage of fatigue life, i.e. $5 \%$ or so. Similar low-high sequence tests with $5 \times 10^{8}$ cycles and $10^{9}$ cycles at low stress levels were performed. Provided that the granular area is not observed after testing, the low stress level applied could be an intrinsic fatigue limit for subsurface fracture. After testing for $5 \times 10^{8} \mathrm{cycles}$, the granular area was observed at a low stress level of $800 \mathrm{MPa}$, but not at $750 \mathrm{MPa}$. After $10^{9}$ cycles, the granular area was not seen at $650 \mathrm{MPa}$, but seen at $700 \mathrm{MPa}$. Therefore, it is concluded that the intrinsic fatigue limit would exist around $650 \mathrm{MPa}$ in the present material.
\end{abstract}

Key Words: Fatigue, Fractography, Iron and Steel, Variable Amplitude Loading Test, Crack Initiation Life, Fatigue Limit, Subsurface Fracture

\section{1. 緒}

高強度鋼や表面処理材では, $S-N$ 曲線に特徴的な 二段折れ曲り現象が現れ, 従来の疲労限度以下の応力 において fish-eye を伴う内部き裂の発生, 進展によっ て破壊を生じる(1) (6).この内部破壊の機構について は不明な点が多く, 内部き裂の発生時期や内部起点形 破壊に対する疲労限度に関しても，直接観察すること が不可能であるために研究は少ない(7)(8).

ところで, 内部起点形破壊において, 内部き裂は非 金属介在物周辺に粒状領域（Granular area）を形成後, fish-eye 乞と遷移し, 本研究のような回転曲げ疲労試 験では fish-eye が試験片表面に達した時点から, 表面 き裂として進展することが知られている(9).また、こ

* 原稿受付 2003 年 12 月 11 日.

*1 正員, 豊田工業高等専門学校機械工学科(画 471-8525 豊田 市栄生町 2-1).

*2 豊田工業高等専門学校専攻科(覀 471-8525 豊田市栄生町 21).

*3 正員, 中日本自動車短期大学( $-505-0077$ 岐阜県加茂郡坂 祝町深萓 1301).

*4 正員, 岐阜大学工学部機械システム工学科( 501-1193 岐 阜市柳戸 1-1)

E-mail : nakajima@toyota-ct.ac.jp
の破壊機構の初期段階に見られる非金属介在物をとり まく粒状領域は，低応力・長寿命域においては認めら れるが, 高応力・短寿命域では現れないことが明らか になっている(9)(10).

本研究では，この粒状領域発生に関する性質を利用 して，それが現れる応力と現れない応力の間で(低 $\rightarrow$ 高)二段二重変動応力試験を行い, 内部き裂発生時期 の推定を行うとともに, 内部き裂発生に対する疲労限 度の実験的推定を試みた。

\section{2. 供試材および実験方法}

$2 \cdot 1$ 供試材供試材料は高炭素クロム軸受鋼 JIS SUJ 2 であり，その化学成分 [mass.\%]は，1.01 C, $0.23 \mathrm{Si}, 0.36 \mathrm{Mn}, 0.012 \mathrm{P}, 0.007 \mathrm{~S}, 0.06 \mathrm{Cu}, 0.04$ $\mathrm{Ni}, 1.45 \mathrm{Cr}, 0.02 \mathrm{Mo}$, Bal. Fe である. 材料には焼 入れ $\left(835^{\circ} \mathrm{C} \cdot 40\right.$ 分保持後油冷 $)$, 焼戻し $\left(180^{\circ} \mathrm{C} \cdot 120\right.$ 分保持後水冷)の熱処理を施しており，熱処理後の機 械的性質は引張強さ $\sigma_{B}: 2316 \mathrm{MPa}$, ビッカース硬さ $H V: 750 \sim 795$ (平均 778), 伸び $\delta: 2 \%$, 絞り $\varphi$ : $0.4 \%$ であ. 熱処理後, 最小断面部直径 $3 \mathrm{~mm}$ の砂 時計形試験片に機械加工した。応力集中係数は 1.06 である.さらに，最小断面部に微粒子ショットピーニ 
ング処理 (Fine Particle Bonbarding 処理：以下, SP 処理)を施した。 SP 処理には，一段めにスチール系ビ ーズ(メッシュサイズ：\#150，アークハイト：0.25 $\mathrm{N} \cdot \mathrm{mm})$ を，二段めにセラミックス硬質ビーズ(メッシ ュサイズ：\# 300，アークハイト：0.08 N・mm)を用い た. SP 処理を施した理由は, 高応力域においても内 部起点形破壊を導くためである.

$2 \cdot 2$ 試験方法本研究では, 実験室大気中にお いて 4 連式片持回転曲げ疲労試験機(繰返し速度 $f=$ $3150 \mathrm{rpm}$ )を用いて試験を実施した.ここでは, fisheye 形成の初期段階に見られる非金属介在物をとりま く粒状領域に注目して, それが認められる応力域(低 応力・長寿命域) と認められない応力域 (高応力・短寿 命域)があることから, それらの応力域の間で(低 $\rightarrow$ 高)二段二重変動応力疲労試験を行った. 実験後, 走 査形電子顕微鏡 $(\mathrm{SEM})$ を用いて, 疲労き裂発生点の 確認および破面様相の観察を行った.

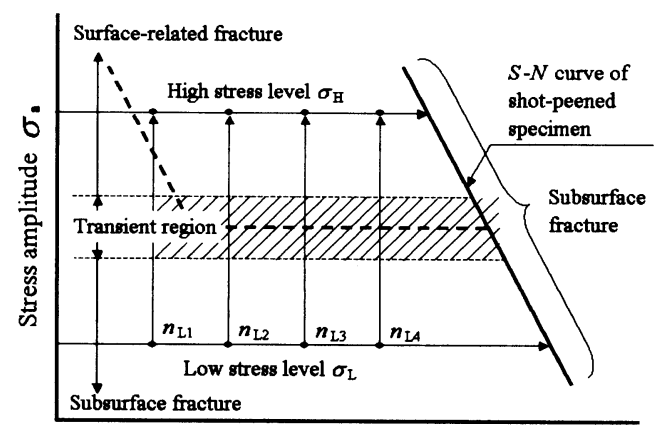

Number of cycles to failure $N_{\mathrm{f}}$

(a) For subsurface crack initiation life

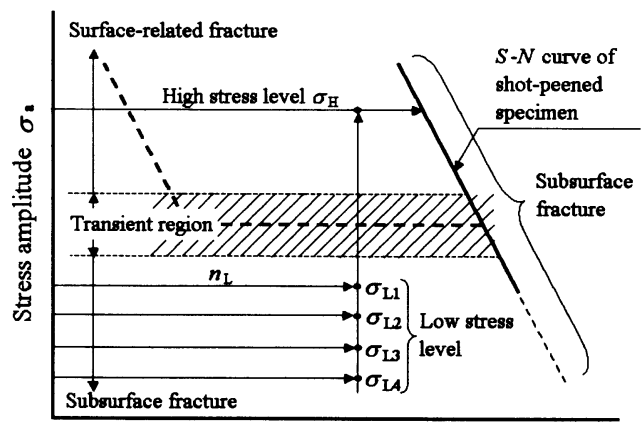

Number of cycles to failure $N_{\mathrm{f}}$

(b) For intrinsic fatigue limit

Fig. 1 Schematic illustrations of two-step variable amplitude loading tests for estimation of subsurface crack initiation lives and intrinsic fatigue limit
$2 \cdot 2 \cdot 1$ 内部き裂発生時期の推定図1(a)およ び ( b ) に, 本実験で用いた変動応力疲労試験の模式図 を示す.図 1( a ) は内部き裂発生時期の推定のための 試験の模式図である。これは先述の粒状領域発生に関 する性質を利用し, 低応力 $\left(\sigma_{L}\right)$ において任意の繰返 し数比 $\left(n_{L} / N_{L}\right)$ に相当する繰返しを与え, その後高応 力 $\left(\sigma_{H}\right)$ に変動させ, 試験片が破断するまで繰返す方 法である. 破断後の破面に粒状領域が認められれば, それは低応力での繰返しの間に形成されたものと考え られるので, そのときの繰返し数比を内部き裂の発生 時期とみなした。後述する $S-N$ 特性から粒状領域の 有無を考慮して, 低応力には $\sigma_{L}=1100 \mathrm{MPa}$, 高応力 には $\sigma_{H}=1600 \mathrm{MPa}$ を選択した。

$2 \cdot 2 \cdot 2$ 疲労限度の推定 図 1 ( b ) の模式図は疲 労限度の実験的推定のためのものである. 図に示すよ うに, 異なる低応力レベル $\left(\sigma_{L 1} \sim \sigma_{L A}\right)$ においてある繰 返し数 $\left(n_{L}\right)$ を与えた後, 高応力 $\left(\sigma_{H}\right)$ に変動させ破断 まで繰返した。破断後, 破面に粒状領域が確認されれ ば，低応力での繰返しの間にき裂は発生したと考えら れる. 確認されなければ fish-eye は高応力において 形成され, 低応力では形成されなかったと考えられる ので, 粒状領域が確認された $\sigma_{L n}$ と確認されなかった $\sigma_{L n+1}$ との間に内部き裂発生に対する疲労限度がある とみなすことができる。ここでは, 低応力として $\sigma_{L}$ $=600 \sim 850 \mathrm{MPa}$, 繰返し数を $n_{L}=5 \times 10^{8}$ および $10^{9}$ と設定し, 高応力には $\sigma_{H}=1600 \mathrm{MPa}$ を選択した.

\section{3. 実 験 結 果}

$3 \cdot 1 S-N$ 特性 一定応力振幅下における疲労 試験により得られた $S-N$ 曲線を図 2 に示す. SP 処 理を施していない試験片 (以下, 未処理材)には特徵的 な二段折れ曲り現象が認められ, $1400 \mathrm{MPa}$ 以上の高

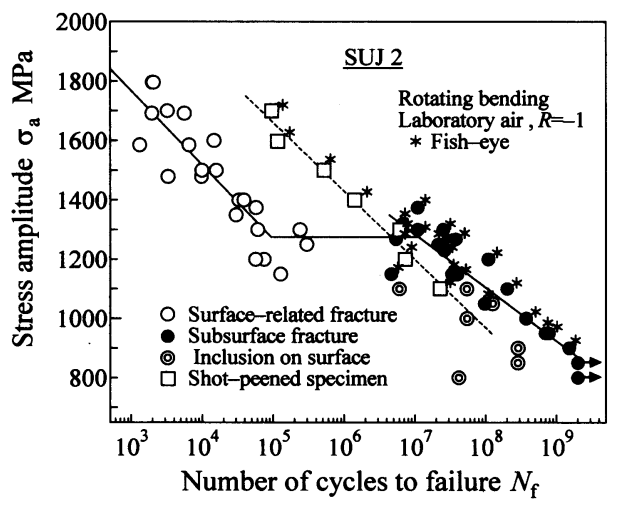

Fig. $2 \quad S-N$ diagrams 
応力域では表面起点形破壊が, $1100 \mathrm{MPa}$ 以下の低応 力域では多くの場合, 内部起点形破壊が生じた。これ らの間の応力域では二つの破壊様式が共存しており， 短寿命側では表面起点形破壊が，長寿命側では内部起 点形破壊が認められた。なお，ステアケース法による

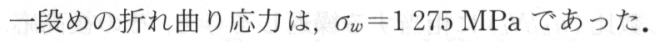
一方, SP材の $S-N$ 曲線には, 試験された応力域にお いて二段折れ曲り現象は認められなかった。これは表 面が硬化されているため表面起点形破壊を生じず, す べて内部起点形破壊を起こしたためである。すなわ ち, 未処理材で表面起点形破壊を生じる応力域におい ても, SP 材では内部起点形破壊を生じ, 疲労寿命は より長寿命側に位置した。また, SP 材の破面観察の 結果, $1400 \mathrm{MPa}$ 以下の応力域では破壊起点である非 金属介在物のまわりに粒状領域が確認されたが, 1500 $\mathrm{MPa}$ 以上の応力域では確認されなかった.

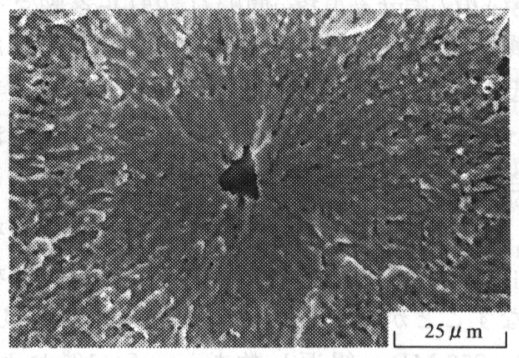

(a) $n_{L} / N_{L}=2.8 \%$

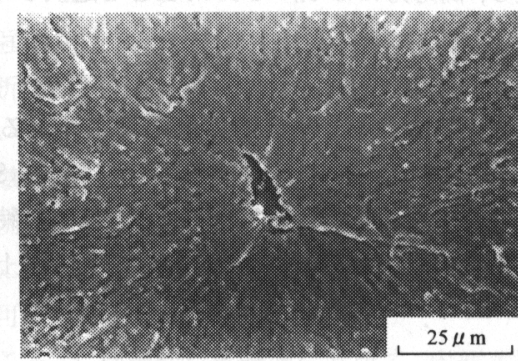

(b) $n_{L} / N_{L}=5.2 \%$

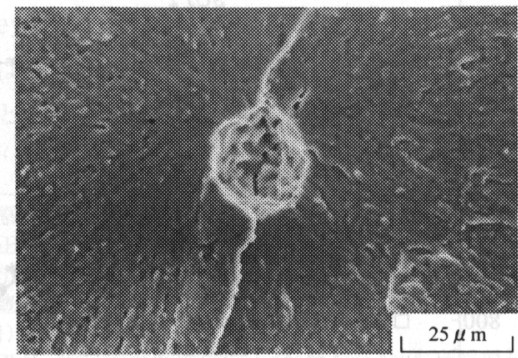

(c) $n_{L} / N_{L}=11.2 \%$

Fig. 3 SEM micrographs of fish-eye formed under variable amplitude loading
$3 \cdot 2$ 内部き裂の発生時期 $3 \cdot 1$ 節の結果より, $1500 \mathrm{MPa}$ 以上の応力で発生した fish-eyeにおいて 粒状領域が確認されなかったため, 粒状領域が発生す る低応力 $\sigma_{L}$ として $1100 \mathrm{MPa}$ を, 粒状領域の発生し ない高応力 $\sigma_{H}$ として $1600 \mathrm{MPa}$ を選択し, 図 1(a) に示す $($ 低 $\rightarrow$ 高) 二段二重変動応力疲労試験を行った. 低応力域における繰返し数は, $1100 \mathrm{MPa}$ にお る一 定応力振幅下の疲労寿命 $\left(N_{L}=2.71 \times 10^{7}\right)$ の $2.8 \%$ 〜92\%とした. 破断後の破面観察の結果, 全試験片 13 本中, $2.8 \%, 5.2 \%$, および $11.2 \%$ の 3 本の試験片を 除く試験片において粒状領域が確認された.

破面観察の結果, 粒状領域の認められなかった破面 の例を図 3( a ), (b ) および ( c ) に示す. $n_{L} / N_{L}=5 \%$ 付近の繰返し数比には 3 本の試験片が用いられてお り，5.2\%の試験片 [図 3(b)]に粒状領域が見られず, 残り 2 本から粒状領域が認められたことは, 内部き裂 の発生が，低応力における疲労寿命の約 $5 \%$ 程度です でに起きていることを示している(7)(8). また, 10\%付 近でも 3 本の試験片を用いて試験が行われているが, ほぼ同じ繰返し数比であるのにもかかわらず, $n_{L} / N_{L}$ $=11.2 \%$ の試験片 [図 3( c )] において粒状領域が認め られなかった.これは, 他の試験片に比べて介在物寸 法 $(\sqrt{\text { area }}=21.5 \mu \mathrm{m})$ が大きく, その寸法が他の試験 片の粒状領域寸法とほぼ同程度であったため, 粒状領 域を経由することなく fish-eyeに遷移したものと考 えられる、これより内部き裂の発生には, 介在物の大 きさ, 形状および位置等によりばらつきが現れること が示唆される.

$3 \cdot 3$ 内部き裂発生に対する疲労限度の推定 内 部き裂発生に対する疲労限度の推定のために図 1 ( b ) に示す $($ 低 $\rightarrow$ 高) 二段二重変動応力疲労試験を行った. 六つの低応力レベル, すなわち $\sigma_{L}=600,650,700$, 750, 800 および $850 \mathrm{MPa}$ において, あらかじめ設定 した繰返し数 $n_{L}=5 \times 10^{8}$ および $10^{9}$ を与え, その後 高応力レベル $\sigma_{H}=1600 \mathrm{MPa}$ へ変動させ, 破断まで 繰返した. $n_{L}=5 \times 10^{8}$ の場合, $\sigma_{L}=800$ および 850 $\mathrm{MPa}$ の 2 本の試験片では粒状領域が確認され, 600〜 $750 \mathrm{MPa}$ の試験片では粒状領域を確認できなか つた。一方 $n_{L}=10^{9}$ の場合, $\sigma_{L}=700$ および $750 \mathrm{MPa}$ の 2 本の試験片では粒状領域が認められ, 600 および $650 \mathrm{MPa}$ の試験片では粒状領域が確認されなかった. 図 4( a ) および (b) は, この試験の結果より得られた 破面の SEM 写真である. 図 $4(\mathrm{a})$ は $\sigma_{L}=650 \mathrm{MPa}$ において $n_{L}=10^{9}$ 繰返された試験片の破面様相で, 非 金属介在物周辺に粒状領域は確認できない. 一方, 図 4 (b) は $\sigma_{L}=700 \mathrm{MPa}$ における結果であり, 介在物周 
辺に明りょうに粒状領域が認められる.この結果よ り, 粒状領域の現れていない $\sigma_{L}=650 \mathrm{MPa} の$ 試験片 は, fish-eye が高応力での繰返しの間に発生したこと を示しており，低応力における繰返し中には，破壊の 原因となるき裂が発生しなかったと考えられる。一 方，粒状領域が現れている $\sigma_{L}=700 \mathrm{MPa}$ の結果では, この内部き裂が低応力での繰返しの間に現れたことを 示している.以上の実験において， $\sigma_{L}=650 \mathrm{MPa}$ 以 下の応力では粒状領域が確認されず，700 MPa 以上で は粒状領域が確認できたことから, 繰返し数 $10^{9} に お ~$ ける内部き裂発生に対する疲労限度は, 650 700 $\mathrm{MPa}$ にあることが示された.

ここで, 図 2 の $S-N$ 曲線における SP 材の寿命(破 線)を最小二乗法によって低応力側へ延長して, 試験 された各応カレベルの寿命を推定すると, $\sigma_{L}=$ $750 \sim 600 \mathrm{MPa}$ において $N_{L}=8.8 \times 10^{8} \sim 3.9 \times 10^{9}$ と なり, $10^{9}$ の繰返しは $\sigma_{L}=650 \mathrm{MPa}$ の推定寿命 $N_{L}=$ $2.4 \times 10^{9}$ の約 $42 \%(1 / 2.4)$ となる. $3 ・ 2$ 節の結果より， 内部き裂発生寿命は寿命比の約 $5 \%$ であると推定され

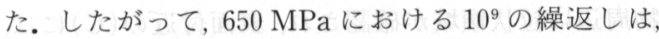
この応力レベルにおいて予想されるき裂発生寿命を大 きく超えていると考えられる.

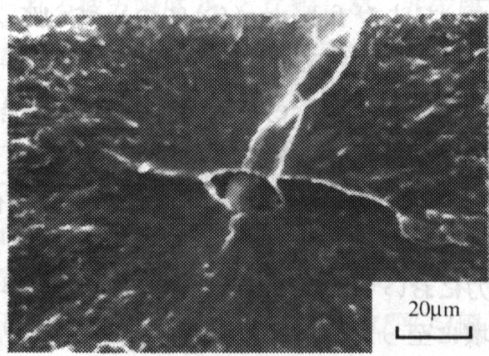

(a ) $\sigma_{L}=650 \mathrm{MPa} \rightarrow \sigma_{H}=1600 \mathrm{MPa}\left(n_{H}=1.53 \times 10^{5}\right)$

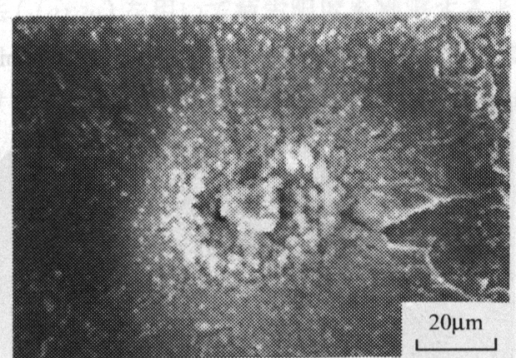

(b) $\sigma_{L}=700 \mathrm{MPa} \rightarrow \sigma_{H}=1600 \mathrm{MPa}\left(n_{H}=4.51 \times 10^{4}\right)$

Fig. 4 SEM micrographs of inclusion and granular area in fish-eye formed under variable amplitude loading $\left(n_{L}=10^{9}\right)$

\section{4. 考察}

$4 \cdot 1 \Delta \boldsymbol{K}$ による評価村上らによる $\sqrt{\text { area }}$ パラ メータモデル(11) を用いて評価した介在物および粒状 領域の応力拡大係数 $\Delta K$ と繰返し数比の関係を図 5 に示す. $\Delta K$ の計算には以下の式を用いた。

$$
\Delta K=0.5 \sigma \sqrt{\pi \sqrt{\text { area }}}
$$

なお,ここで用いた $\sigma$ は介在物の位置における応力で ある.また, 図中 $n_{L} / N_{L}=1$ の結果(右端の点) は 1100 $\mathrm{MPa}$ における一定応力振幅下で破壞に至った試験片 のものであり, それ以外の実験点 $\left(n_{L} / N_{L}=2.8 \%\right.$ 〜 $92 \%$ ) は, 二段二重変動応力振幅下で得られたもの である。

$n_{L} / N_{L}=2.8 \% \sim 92 \%$ の間では, 介在物の $\Delta K$ 值は $2.5 \sim 3.5 \mathrm{MPa} \sqrt{\mathrm{m}}$ となる.一方粒状領域の $\Delta K$ 值は 3.1〜 4.1 MPa $\sqrt{\mathrm{m}}$ となり, その大きさは全繰返し数 比を通じてほとんど変化しない.これらの值と比べて 一定応力振幅下における粒状領域の $\Delta K$ 值は大きく, $\Delta K=5.3 \mathrm{MPa} \sqrt{\mathrm{m}}$ であった。以上のことから，粒状 領域から fish-eyeへの遷移は寿命の $90 \%$ を超える繰

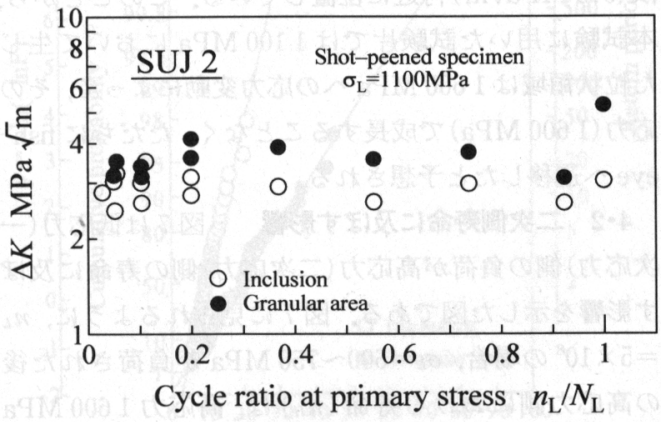

Fig. 5 Relationships between $\Delta K$ values for inclusion and granular area and cycle ratio at primary stress $\left(\sigma_{L}=1100 \mathrm{MPa}\right)$

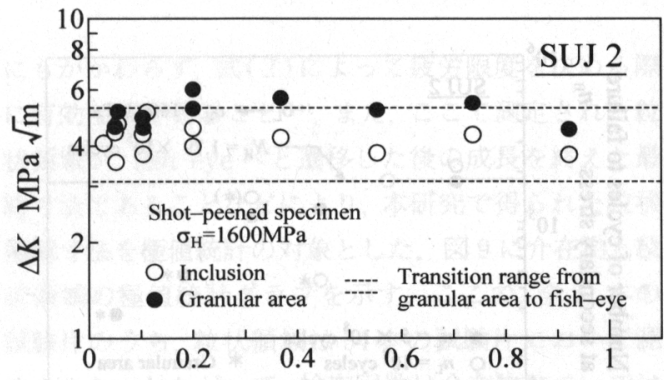

Cycle ratio at primary stress $n_{\mathrm{L}} / N_{\mathrm{L}}$

Fig. 6 Relationships between $\Delta K$ values for inclusion and granular area and cycle ratio at $\sigma=1600$ $\mathrm{MPa}$ 
返し域で生じることが予想されるが(8), この粒状領域 の成長機構の詳細については今後の課題である.

図 6 は $1600 \mathrm{MPa}$ の応力レベルにおいて粒状領域 が認められなかった理由について検討した図である。 図中の破線は, $1100 \mathrm{MPa}$ における一定応力振幅下で 得られた粒状領域から fish-eye へ遷移する際の $\Delta K$ の範囲(3.1〜 $5.3 \mathrm{MPa} \sqrt{\mathrm{m}})$ を表している. 図4 の結 果を導いた同じ介在物に対して，仮に最初から $\sigma=$ $1600 \mathrm{MPa}$ を負荷したとすると,介在物の $\Delta K$ 值 $(O$ 印) はすべて, 粒状領域から内部き裂への遷移を生じ る $\Delta K$ の範囲(破線の間) に入ることになる。このこ とから $1600 \mathrm{MPa}$ では, 介在物の $\Delta K$ 值が粒状領域 から内部き裂への遷移領域に入るため, 介在物は粒状 領域を経ないで直接 fish-eye を発生させたものと推 定される.一方, 同様の $\Delta K$ の範囲を図 5 に適用すれ ば, 図示はしていないが, 介在物の $\Delta K$ 值(○印)は, ほとんどが遷移範囲の下限 $(3.1 \mathrm{MPa} \sqrt{\mathrm{m}})$ 以下とな る.したがって,この場合は粒状領域を形成し, fisheye へ遷移することになる。また, 図 6 における粒状 領域の $\sigma=1600 \mathrm{MPa}$ における結果は, 高応力への変 動後の $\Delta K$ 值を示しているが, 全体的に遷移範囲の上 限 $(5.3 \mathrm{MPa} \sqrt{\mathrm{m}})$ 付近に位置している.このことから， 本試験に用いた試験片では $1100 \mathrm{MPa}$ において生じ た粒状領域は $1600 \mathrm{MPa}$ への応力変動によって，その 応力 $(1600 \mathrm{MPa})$ で成長することなく, ただちに fisheyeへ遷移したと予想される.

$4 \cdot 2$ 二次側寿命に及ぼす影響 図 7 は低応力 (一 次応力) 側の負荷が高応力 (二次応力) 側の寿命に及ぼ す影響を示した図である。図 7 に見られるように， $n_{L}$ $=5 \times 10^{8}$ の場合, $\sigma_{L}=600 \sim 750 \mathrm{MPa}$ が負荷された後 の高応力側における寿命 $\left(n_{H}\right)$ は, 高応力 $1600 \mathrm{MPa}$ での一定応力振幅下の疲労寿命 $\left(N_{H}=1.79 \times 10^{5}\right)$ とほ ぼ同じであるのに対して, $800 \mathrm{MPa}$ 以上が負荷された

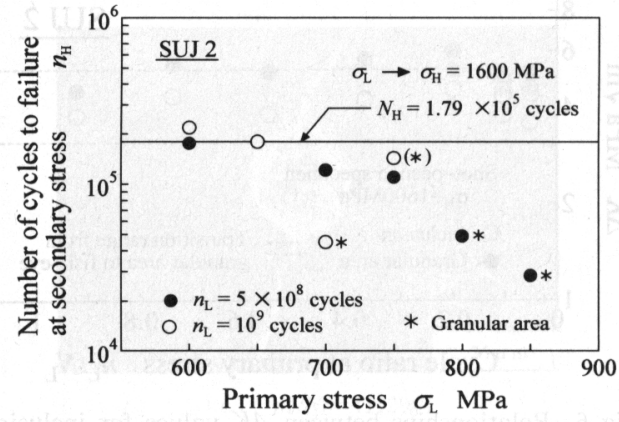

Fig. 7 Relationships between number of cycles to failure at secondary stress and primary stress
後の寿命は大きく低下している. 一方, $n_{L}=10^{9}$ の場 合, $\sigma_{L}=600$ および $650 \mathrm{MPa}$ が負荷された後の高応 力側における寿命 $\left(n_{H}\right)$ は, 高応力 $1600 \mathrm{MPa}$ での一 定応力振幅下の疲労寿命とほぼ同じであるのに対し て, $700 \mathrm{MPa}$ が負荷された後の寿命は大きく低下して いる.すなわち $n_{L}=5 \times 10^{8}$ の場合, $800 \mathrm{MPa}$ 以上, $n_{L}=10^{9}$ の場合, $700 \mathrm{MPa}$ 以上の応力で, 一次応力負 荷の間に破壊の原因となるき裂が発生し, 二次応力で の負荷において，そのき裂が成長して破壊に至ったた め, 二次応力での寿命が減少したと考えられる。一方, $n_{L}=5 \times 10^{8}$ では $750 \mathrm{MPa}$ 以下, $n_{L}=10^{9}$ では 650 $\mathrm{MPa}$ 以下の一次応力負荷の間には, 破壊の原因とな るき裂が発生しなかったことを示している。これは粒 状領域の観察結果ともよく一致している.

図 7 における $n_{L}=10^{9}, \sigma_{L}=750 \mathrm{MPa}$ の結果は, 二 次応力側において疲労寿命 $\left(n_{H}\right)$ が低下しなかった。 この試験片の破面様相を図 8 に示す. 図 8 から明らか なように, 三つの fish-eye が発生している。このうち 内部に存在する $(\mathrm{A})$ および (B)の fish-eyeには介在 物周辺に粒状領域が確認され, 表面付近の (C)には, 介在物周辺に粒状領域は認められなかった。 介在物お よび粒状領域に関する $\Delta K$ 值は, fish-eye (A)につい て $\Delta K_{\text {incA }}=2.2 \mathrm{MPa} \sqrt{\mathrm{m}}, \Delta K_{\text {gaA }}=4.9 \mathrm{MPa} \sqrt{\mathrm{m}}$, fish eye (B)について $\Delta K_{i n c B}=2.4 \mathrm{MPa} \sqrt{\mathrm{m}}, \Delta K_{g a B}=3.4$ $\mathrm{MPa} \sqrt{\mathrm{m}}$, および fish-eye (C)について $\Delta K_{\text {incc }}=1.9$ $\mathrm{MPa} \sqrt{\mathrm{m}}$ であった. 破面観察から $n_{L}=10^{9}$ の一次応力 負荷の間に内部に fish-eye (A)および $(\mathrm{B})$ が発生した が, 二次応力への変動後に, これらの fish-eye は破壊 を導かなかったと考えられる。一方，表面付近の fish-eye (C) は粒状領域が確認されなかったことから, 二次応力において発生したと推定され。これを起点と して破壊に至ったと推論される。こうしたことから， 二次応力における疲労寿命の低下は見られなかった

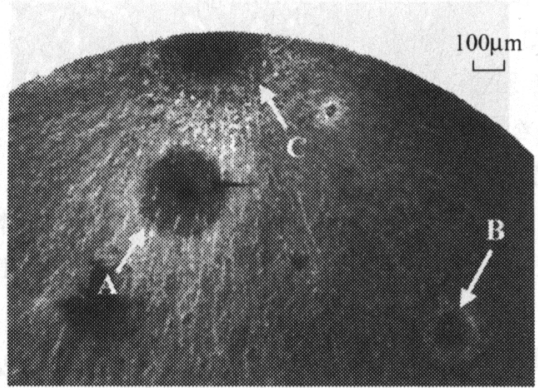

Fig. 8 SEM micrograph of three fish-eyes formed under variable amplitude loading $\left(\sigma_{L}=750 \mathrm{MPa}, n_{L}=10^{9}, n_{H}=1.43 \times 10^{5}\right)$ 
Table 1 Fatigue limit estimated by $\sqrt{\text { area }}$ parameter model

\begin{tabular}{|c|c|c|c|c|c|c|}
\hline \multirow{2}{*}{$\begin{array}{c}\text { Hardness } \\
(H V)\end{array}$} & \multicolumn{4}{|c|}{ Inclusion : Varea $[\mu \mathrm{m}]$} & \multicolumn{3}{c|}{ Granular area: Varea $[\mu \mathrm{m}]$} \\
\cline { 2 - 8 } & Max. 21.5 & Min. 5.3 & Ave. 10.4 & Max. 45.4 & Min. 6.5 & Ave. 20.8 \\
\cline { 2 - 7 } & \multicolumn{6}{|c|}{ Fatigue limit : $\sigma_{\mathrm{w}}[\mathrm{MPa}]$} \\
\hline Max. 795 & 856 & 1081 & 966 & 756 & 1045 & 860 \\
\hline Min. 750 & 814 & 1028 & 918 & 719 & 993 & 818 \\
\hline Ave. 778 & 840 & 1061 & 948 & 742 & 1025 & 844 \\
\hline
\end{tabular}

Table 2 Fatigue limit estimated by statistics of extremes

\begin{tabular}{|cc|c|c|}
\hline \multirow{2}{*}{$\begin{array}{c}\text { Hardness } \\
(H V)\end{array}$} & \multicolumn{2}{|c|}{ Inclusion $:$ Varea } & Granular area : Varea \\
\cline { 2 - 4 } & $F=99.9 \%: 29.4[\mu \mathrm{m}]$ & $F=99.9 \%: 73.4[\mu \mathrm{m}]$ \\
\cline { 2 - 4 } & \multicolumn{2}{|c|}{ Fatigue limit : $\sigma_{\mathrm{w}}[\mathrm{MPa}]$} \\
\hline Max. 795 & 813 & 698 \\
\hline Min. & 750 & 773 & 663 \\
\hline Ave. & 778 & 797 & 685 \\
\hline
\end{tabular}

が, fish-eye (A) および(B)が, なぜ高応力のもとで 破壊を導かなかったかについては不明である.

$4 \cdot 3$ 極值統計による推定本実験で得られた疲 労限度を村上らによる $\sqrt{\text { area }}$ パラメータモデルを用 いて得られる疲労限度 $\sigma_{w}$ と比較した。非金属介在物 が表面から離れた内部に存在していたため, 次式(12) を用いて $\sigma_{w}$ を評価した。

$$
\sigma_{w}=1.56(H V+120) /(\sqrt{\text { area }})^{1 / 6}
$$

ここで, ビッカース硬さ $(H V)$ として, 測定によっ て得られた最大値, 最小值および平均値を用いた。一 方, 介在物ならびに粒状領域の寸法として, 全 41 本の 試験片における最大值, 最小值および平均值を用い た。

結果を表 1 に示す．表 1 から明らかなように, 介在 物寸法 $(\sqrt{\text { area }})$ を用いて疲労限度を推定すると $\sigma_{w}=$ 814〜1 $081 \mathrm{MPa}$ となり，いずれの值も内部き裂発生 における実験結果より高くなる。一方, 粒状領域寸法 を用いると， $\sigma_{w}=719 \sim 1045 \mathrm{MPa}$ となり， $n_{L}=5 \times$ $10^{8}$ の内部き裂発生における実験結果はこの範囲に含 まれる。しかし, $n_{L}=10^{9}$ の場合, 疲労限度は 650〜 700 MPa となり, 推定値より低い.

そこで, 極值統計により介在物および粒状領域の最 大值を予測し, 疲労限度の推定を試みた ${ }^{(13)}$. 粒状領域 寸法を統計量として用いることは，それが介在物の位 置, 負荷応力および繰返しによって変化する量である

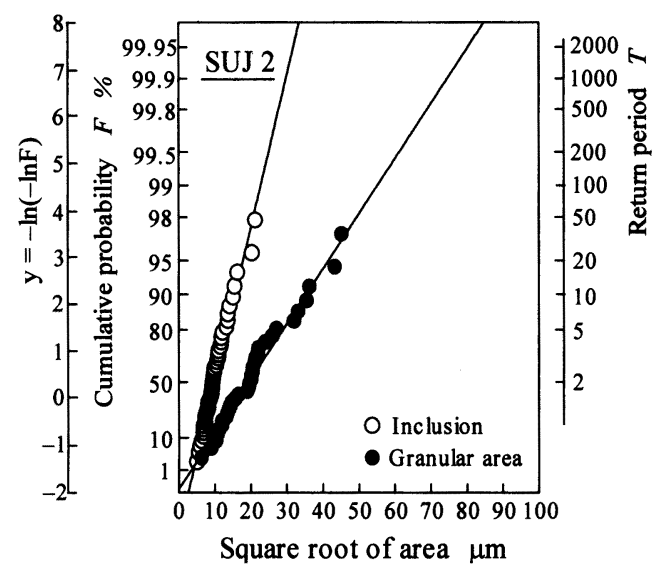

Fig. 9 Statistics of extreme distribution on inclusions and granular areas

にもかかわらず, 式 ( 2 )によって疲労限度を決める際 に有効な値であること(14), また, ここで測定された粒 状領域が, fish-eyeへと遷移した後の成長を終えた最 終寸法であることなどにより, 本研究で得られた粒状 領域寸法を極值統計の対象とした. 図 9 に介在物と粒 状領域の極值統計グラフを示す.ここで, 全 41 本の 試験片のうち, 粒状領域は 34 本の試験片において認 められた. したがって, 検査回数は介在物については $n=41$, 粒状領域については $n=34$ とした.

疲労限度の計算結果を表 2 に示す.一定応力振幅下 の累積確率 $F=99.9 \%$ に対する介在物寸法は 29.4 
$\mu \mathrm{m}$ となり,これを用いて式(2)によって推定された 疲労限度は $\sigma_{w}=773 \sim 813 \mathrm{MPa}$ となる. 一方, 粒状領 域寸法は $73.4 \mu \mathrm{m}$ であり, 疲労限度は $\sigma_{w}=663 \sim 698$ $\mathrm{MPa}$ となる。これは $n_{L}=10^{9}$ の結果から得られた実 験值 $\sigma_{a}=650 \sim 700 \mathrm{MPa}$ の範囲に含まれる。これよ り, $F=99.9 \%$ における粒状領域寸法の統計的推定値 を用いた場合に実験結果と良い一致が認められたこと になるが，実験結果を導いた介在物等は図 4 に示すと おりで, 統計的推定值よりも小さい. 本研究における き裂発生ということと式 ( 2 )の意図する疲労限度とい う考え方に, 式を適用する上でのなんらかのそごが示 唆されるが詳細は不明であり, 今後の課題としたい.

\section{5. 結}

fish-eye 形成の初期段階に見られる非金属介在物を とりまく粒状領域に注目して，それが現れる低応力と 現れない高応力の間で (低 $\rightarrow$ 高)二段二重変動応力疲労 試験を行い, 内部き裂発生寿命ならびに内部き裂発生 に対する疲労限度の実験的推定を試み, 以下の結論を 得た。

（1）低応力側における繰返し数比を $2.8 \%$ から 92\%まで変えて行った内部き裂発生寿命推定のための 試験において, 繰返し数比 $5 \%$ 程度の試験片から粒状 領域が確認された。これより破断の原因となる内部き 裂は, 疲労寿命のごく初期の段階ですでに発生してい ることが示された。

（2）上記実験において, 繰返し数比 $11.2 \%$ の場合 粒状領域が現れない試験片が認められた。これより内 部き裂の発生する時期には，ばらつきがあることが明 らかとなった。

（3）粒状領域に応力拡大係数 $\Delta K$ を用いて評価 した結果, 粒状領域は疲労初期に出現し, その後寸法
を変えず, 疲労寿命の $90 \%$ を超えた寿命域において fish-eye へ遷移し，破断に至ることが示唆された。

（4）本研究において用いた材料(SUJ 2)の内部き 裂発生に対する疲労限度は, $5 \times 10^{8}$ 回の繰返しに対し ては 750〜800 MPa，また $10^{9}$ 回の繰返しに対しては 650〜700 MPa であると推定された.

（5）介在物および粒状領域の寸法から極值統計を 用いて疲労限度を推定した結果，累積確率 $F=99.9 \%$ における粒状領域寸法に対する疲労限度が 660 〜 700 $\mathrm{MPa}$ と予想され, $10^{9}$ 回の繰返しにおける内部き裂発 生応力と良い一致を示した。

本研究を実施するにあたり, 当時豊田工業高等専門 学校学生・牧知弘君の協力を得た。記して謝意を表す る.

\section{文献}

（1）内藤武志・植田秀夫 - 菊池雅男, 材料, 32-361（1983）, 1162-1166.

（2）江村秀樹 - 浅見克敏，機論，55-509，A（1989），45-50.

（3）村上敬宜・野本哲志・植田徽 - 村上保夫 - 大堀学, 材料, 48-10 (1999), 1112-1117.

（4）勝谷悟志・黒島義人・原田昭治，材料，48-10（1999）, 1107-1111.

（5）塩澤和章 - 魯連涛 - 石原外美, 材料, 48-10（1999）, 1095 1100.

（6）酒井達雄 - 武田光弘 - 塩澤和章 - 越智保雄 - 中島正貴 中村孝・小熊規泰, 材料, 49-7 (2000), 779-785.

（7）黑島義人・斎藤康弘・清水真佐男・川䓂一博, 機論, 60 580, A (1994) 2710-2715.

（8）魯連涛 - 塩澤和章, 機論, 68-675, A (2002), 1666-1673.

（9）中島正貴 - 酒井達雄 - 清水利弘, 機論, 65-640, A (1999), 2504-2510.

（10）村上敬宜 - 植田徹 - 野本哲志 - 村上保夫, 機論, 66-642, A (2000), 311-319.

（11） 村上敬宜 - 児玉昭太郎 - 小沼静代，機論， 54-500， A (1988), 688-696.

（12）村上敬宜 - 遠藤正浩, 材料, 35-395（1986）, 911-917.

（13）村上敬宜・宇宿尚史, 機論, 55-510, A (1989), 213-221.

（14）長田淳治・村上敬宜, 材料, 52-8（2003），966-973. 